the following year. And Mills is also sound in showing how the more radical members of Quebec's feminist movement drew from decolonization discourse and anti-colonial paradigms to elaborate their own critique of patriarchal norms and practices by decades' end. For those interested in brushing up on such aspects of Montreal radicalism in the decade of the 1960s, Mills' book is a good place to start.

Alexis Lachaîne York University

\title{
Martha Elizabeth Walls, No Need of a Chief for This Band: The Maritime Mi'kmaq and Federal Electoral Legislation, 1899-1951 (Vancouver: UBC Press, 2010).
}

Using the Mi'kmaq as a case study, Martha Elizabeth Walls examines the creation and imposition of federal electoral legislation in maritime Canada between 1899 and 1951 and the various ways in which indigenous communities accepted, rejected, and deflected its assimilationist purpose. Indebted to colonial-era Indian policy in the Canadas - which also sought the "gradual civilization of the Indian tribes" - the 1899 amendments to the Indian Act aimed to replace indigenous forms of governance, in all their variety, with a standardized band council system. By electing their chiefs and councilors every three years under the auspices of a local Indian agent, Walls recounts, the federal government hoped to accomplish in the realm of politics what reserve life and aboriginal schools sought in the areas of economics and culture: the elimination of the Indian as an Indian.

It did not quite work out that way. While the new "triennial" system enhanced the influence of superintendents and local Indian agents over local political affairs - it was now possible for them to unilaterally depose an elected chief - the Mi'kmaq themselves never fully succumbed to the letter or intent of the new laws. Instead, as Walls demonstrates, a form of "political syncretism" evolved on Mi'kmaw reserves, as communities across the region combined existing forms of indigenous governance (which in themselves had evolved over centuries of encounter with Europeans) with elements of the new federal system to defend and often expand the scope of their own autonomy. In the end, this resistance, coupled with the absence of essential state resources (both financial and human) to properly administer the new electoral legislation, not only undermined the law's assimilationist objectives, but acted as a catalyst for contemporary struggles for indigenous rights.

Developed over five tightly focused chapters, Walls's argument is persuasive in many ways. To her immense credit, she situates her analysis of twentieth-century Mi'kmaw politics in the deeper history of native-newcomer encoun- 
ters in the region, which stretch back to the late 1500s and early 1600s. In doing so, Walls neutralizes the notion that a singular, static moment of authentic, purely Mi'kmaw politics ever existed, and conveys instead a portrait of constant change and adaptation: political syncretism, in other words, had always been a feature of indigenous life, whether the Mi'kmaq were negotiating with the Abenaki, supporting the French, or fighting the British. Equally impressive is Walls's region-wide perspective, especially in the chapters dedicated to the triennial system. With examples from Lennox Island (Prince Edward Island), Burnt Church (New Brunswick), or Eskasoni (Nova Scotia) - to name but three - she makes clear not only the diverse ways in which the Mi'kmaq responded to the new federal legislation - from indifference to opposition — but also a host of common issues that the new electoral system either called into being or drew to the surface.

Yet for all its virtues - I might also have mentioned the book's jargonfree prose, well-chosen images, and relevance to contemporary issues - No Need of a Chief for This Band was not entirely satisfying, for while it addresses a new subject, it advances an overall argument that is by now familiar: twentieth-century indigenous politics were defined, in large measure, by "resistance, accommodation, and cultural survival."(131) Indeed, as I turned the book's last page, I had the distinct sense that more could have been said, the analysis pushed further. Numerous anecdotes presented in the text indicate that the struggle over the triennial system intersected with a wide range of other political issues fundamental to Mi'kmaw life: territoriality, treaty memories, and the very definition of who was and was not a Mi'kmaw person. That experiments in pan-Indianism and creation of new political regalia, such as the flag of the Grand Council, were taking place at the same time suggests that a much deeper form of political reorientation - at the level of thought, even ontology — was taking place among the Mi'kmaq as the nineteenth century gave way to the twentieth. The conceptual categories of "resistance, accommodation, and cultural survival" capture part of this process, but they don't really capture it all. Perhaps an additional chapter dedicated to a single community over a period of time, crafted with an eye toward drawing the strands of these varied yet related political issues together, was warranted.

My point here is not that Walls should have written a different book or that I am ungrateful for the analysis that she did produce. Far from it: No Need of a Chief for This Band opens up some important historiographical questions and has obviously got me thinking. My point is simply that the argument advanced by this book seems somewhat timid, in light of the evidence presented. That evidence suggests a dynamic link between changes in political structures and processes (on the one hand) and the (re)definition of individual and collective identities (on the other). How that process actually took place in the Mi'kmaw context remains to be fully explored; so, too, does a new way to conceptualize 
the relationship between the state, law, and indigenous people.

Andrew Parnaby,

Cape Breton University

\section{David Frank and Nicole Lang, Labour Landmarks in New Brunswick (Canadian Committee on Labour History, 2010).}

Labour Landmarks in New Brunswick explores a fascinating but little known aspect of New Brunswick's cultural heritage - the tradition of commemorating the sacrifices and contributions of the province's workers through the creation of labour landmarks. (10)

Crafted by award winning labour historians David Frank and Nicole Lang, with a skilled team of assistants and supporters, it is the most recent offering of Labour History in New Brunswick (lhtnb.ca), a community-university research alliance devoted to fostering an informed public memory related to the history of work in the province.

The authors explain that their study was inspired by the work of Archie Green who, in the 1950s, first began to draw attention to "laborlore" and other working class traditions that typically went unnoticed by historians and folklorists. The present study is limited to one such form of expression - a selection of markers that commemorate the experiences of work and workers in $20^{\text {th }}$ century New Brunswick. The book reads like a fireside chat, traveling across the province, monument by monument, telling the story of how lives were lived, how lives were lost, and how communities came together to ensure that their history would not be forgotten.

Presented in ten brief chapters, in French and in English, Labour Landmarks discusses memorials found in both public and private places, beginning with those erected by families, by unions, and by other workers' organizations. It goes on to consider markers that commemorate the history of work and workers in the major high-risk sectors of the province's traditional economy, including firefighters and coal miners, railway workers and fishermen, mill and forestry workers. A separate chapter examines the Labour movement's "invented tradition" of the April 28 "Day of Mourning" (67) and efforts to raise awareness around the issues of workplace safety and the right to refuse unsafe work. (73)

The book includes 47 photographs of labour markers and of people gathered at these sites for memorial ceremonies (62). These images are placed throughout the book and are interpreted within the text, with photo credits grouped together at the back, following a section of 72 explanatory endnotes. The book concludes with a map and a list of 50 labour landmarks in the 